\title{
The Use of Instagram as Media for Stunting Campaign: Analysis on Gen Z Knowledge
}

\author{
Lathifah Dzakiyyah Zulfa* \\ Faculty of Medicine, Universitas Kristen Indonesia
}

*Corresponding author:

E-mail:

Lathifahdzakiyyahz@gmail.com

\begin{abstract}
The long-term impacts of stunting are very diverse, such as cancer, diabetes, anemia, or stupidity, and will interfere with the productivity of the individual itself. The right educational media is needed to raise awareness of the young generation so that changes in the mindset of choosing food (nutritional intake) can start now and prevent stunting in future offspring. Z generation students as samples were given education through Instagram uploads from the @ChangeTheCircle account with the tag \#ChangeTheCircle, after previously being asked to do a pretest. The pretest-posttest scores' mean from the intervention and control groups were then tested for significance by using paired t-test. Not forgetting to see a difference in initial ability, the researcher tested the unpaired t-test and $U$ test on the two groups' pretest and posttest. The intervention group $(P<0.05)$ showed a significant difference between pretest and posttest scores while the control group did not. The difference in initial ability as measured through the comparison of pretest scores was counted insignificant, so there was no bias from the sample's initial knowledge in the control or intervention groups to the posttest results. The campaign on stunting issues through Instagram posts with the tag \#ChangeTheCircle has an impact on the reader's ability to answer questions, indicating that this campaign has succeeded in increasing their knowledge of stunting.
\end{abstract}

Keywords: Instagram, social campaign, stunting

\section{Introduction}

The incidence of stunting in Indonesia has reached 36.4\% from 2005 to 2017, making a third of children under five years old in Indonesia experience stunting. This rate gives Indonesia a title as the third country with the highest incidence of stunting in the Southeast Asia region. Stunting is a nutritional problem with the highest prevalence in Indonesia. This problem tends to be static (no decrease in the number of events over time) and the last stunting bulletin published by the Ministry of Health was in 2018 so that the community itself still has difficulty accessing information about stunting (Kurniasih, 2018). The impact of stunting is not only being short but so many other events that are causing concern and detrimental to many sectors, including other countries in the long term (Ampaabeng \& Tan, 2013).

Children's brain development will be affected by stunting so later on they can not think critically and creatively (Ampaabeng \& Tan, 2013; Abdi et al., 2021; Belachew et al., 2011; Osei \& Lambon-Quay Fio, 2021; Hererimana, 2020). Some studies prove that the level of reactive oxygen species in stunted children is higher than in taller children, so diseases with an inflammatory basis such as diabetes mellitus, ischemic heart disease, and cancer may be more prone to attack stunting children later in life (Samy et al., 2014; Bhutta et al., 2017; Jiang et al., 2021; Alam et al., 2021; Children with disabilities report, 2013; Asiki et al., 2019; Grillo \& Gigante, 2017). Their productive period will certainly be dis- 
rupted if they have to deal with this disease so that again it will interfere with human resources (Children with disabilities report, 2013). The cycle of poverty can occur as a result of the long-term impact of stunting, which means that a vicious cycle of stunting will also be formed. Stunted children will grow into malnourished adolescents, then when they get pregnant, the baby is not well nourished, and the baby born with may also be stunted (Prendergast \& Humphrey, 2014). Do not forget about the low immune power in children with nutritional problems, which leads to infectious diseases. This will make it difficult for the state to eradicate infectious diseases (Osei \& Lambon-Quay Fio, 2021; Nadila, 2021).

In the mission to make Indonesia stunting-free and preventing stunting complications, people's awareness needs to be raised as they are the only ones who can care more about themselves. Social media like Instagram can be a good platform to raise people's awareness. There are dozens of Instagram accounts driving the campaign to eradicate stunting on Instagram and more than 500 posts with the hashtag \#StuntingIndonesia on Instagram. Not only provides education about the characteristics, risk factors, and impact of stunting, there it also information on nutritious foods that attracts the attention of researchers to see the significance of the effect of social campaigns on readers' knowledge. This study aims to prove that social campaigns through Instagram can raise $Z$ generation awareness by educating them.

\section{Material and Methods}

The research design used was a quantitative descriptive study with a pretest-posttest control design without randomization so that it was included in the quasi-experiment category. The correlation approach to two variables (the pretest and the posttest score) was carried out in this study (Aisyah et al., 2020). The 140 first-year students of the Faculty of Medicine at the Christian University of Indonesia became the population of this study because they had not formally studied stunting from expert course materials. Guided by Lemeshow et al, the sample calculation will be:

$$
N 1=N 2=2 \cdot \sigma^{2}(Z(1-\alpha)+Z(1-\beta))^{2} /(u 1-u 2)^{2}
$$

With :

N1: Sample on the intervention group

N2: Sample on control group

$\sigma^{2}:$ Standard deviation

$Z(1-\alpha): Z$ value with $95 \%$ confidence level

$Z(1-\beta): Z$ value with $90 \%$ test strength

$u 1:$ The difference of the mean pretest-posttest in the intervention group

u2: The difference of the mean pretest-posttest in the control group

$$
\mathrm{N} 1=\mathrm{N} 2=2.0,9^{2}(1,96+1,28)^{2} /(1-0)^{2}=17,006 \sim 17
$$

After conducting a preliminary test, a standard deviation is 0,9 and the difference in the mean pretest-posttest in the intervention group was 1 (u1) and the control group was 0 (u2). With a confidence level of $95 \%$ and a test strength of $90 \%$ so that the $Z$ value is 1.96 and 1.28 respectively, the number of samples for each group is 17 people (Lemeshow et al., 1994). To avoid dropout, the sample becomes 19 people per group with the following calculations:

$$
\mathrm{n}=\mathrm{N} / 1-10 \%=171-10 \%=18,88 \sim 19
$$

The data processing begins with the scoring process by calculating the correct answers and adding it up with 10 points for each question in the instrument that measures the sample's knowledge of stunting in terms of definition, risk factors, impact, and treatment (the score will range from $0-100$ points). The normality test is then carried out to determine a suitable correlation significance test in 
the form of paired sample t-test (normally distributed data) or a Wilcoxon test (if the data is not normally distributed). An unpaired t-test was also performed on the posttest score and the $U$ test on the pretest score to determine the difference in scores between the two groups (Aisyah et al., 2020).

\section{Results and Discussion}

Instagram dominates respondents' choices as their most visited social media (76\%). There is a difference between the highest post-test scores of the intervention group and the control group. As shown in table 1 , the mean of pre-test and post-test scores also differed between the two groups, namely by 14.27 apart (obtained from $(59$ - 43.68) - (50.52 - 49.47)). There is also a difference in the Tpaired significance value of the pre-test post-test where the intervention group is below the limit of significance level $(<0.05)$. This study revealed a significant increase in the scores before and after being given the intervention which indicated the success of the intervention in increasing the sample test scores. This is evidenced by the P-value of $0.004(<0.05)$ which means that there is an educational influence in the form of social campaigns through Instagram @ChangeTheCircle to generation Z students (represented in this study by students of the Faculty of Medicine, Christian University of Indonesia, class of 2020).

Table 1. Comparison of two groups' score

\begin{tabular}{ccccc}
\hline Component & \multicolumn{2}{c}{ Control Group } & \multicolumn{2}{c}{ Intervention Group } \\
& Pre-test & Post-test & Pre-test & Post-test \\
\cline { 2 - 5 } & 19 & 19 & 19 & 19 \\
\hline Total $(\mathrm{n})$ & 20 & 40 & 20 & 40 \\
Minimal Score & 70 & 60 & 60 & 80 \\
Maximum Score & 50 & 50 & 50 & 50 \\
Hypothetical & \multicolumn{2}{|c}{$0,004(<0.05)$} \\
$\quad$ Mean & 50,52 & 49,47 & 43,68 & \\
Empirical mean & \multicolumn{2}{c}{$0,429(>0.05)$} & & \\
Significancy score & \multicolumn{2}{c}{0} \\
(T-paired) & &
\end{tabular}

Free, easy, and pleasing to see become the reasons why education through Instagram can boost its follower knowledge effectively, although it can lead to unfocus and depends on internet signal (Ambarsari, 2020). Research conducted by Sesriyani shows Instagram using can help the student to get a good grade on English test in Universitas Pamulang (Sesriyani \& Sukmawati, 2019). Another study also shows a linear result like the higher motivation of students from SMAN 2 Banda Aceh because of Instagram as their studying media (Ramadhani, 2019). With interesting pictures and videos, learning will be more fun so that this learning method becomes effective

The post-test significance value of the two groups was below the limit of the significance level with the unpaired t-test while the pre-test with the $U$ test exceeded the significance level. The mean pretest scores of the two groups were indeed different, but the $\mathrm{U}$ test showed no significant difference ( $P$ 0.064> 0.05) so that there was no bias towards the respondents' prior knowledge (Table 2). Generation Z's knowledge of stunting was increased by this social campaign, without any influence on how much prior knowledge of the research subjects both in the intervention group and those without because their prior knowledge was equal. 
Table 2. Comparison of pretest and posttest score

Component Pre-test Post-test

\begin{tabular}{ccccc} 
& Control group & $\begin{array}{c}\text { Intervention } \\
\text { group }\end{array}$ & Control group & $\begin{array}{c}\text { Intervention } \\
\text { group }\end{array}$ \\
\hline Total $(\mathrm{n})$ & 19 & 19 & 19 & 19 \\
Empirical mean & 50,52 & 49,47 & 43,68 & 59 \\
Significancy score & \multicolumn{2}{c}{$\cup 0,064(>0.05)$} & \multicolumn{2}{c}{ t $0,017(<0.05)$} \\
\hline
\end{tabular}

\section{Conclusion}

Social campaigns on Instagram can enhance $Z$ generation knowledge so providing education (as a first step to make the younger generation aware of the importance of the issue of stunting) can be done as easily as uploading a photo containing information with an attractive design. This knowledge becomes a provision for change, which mainly starts within the person himself so that in the future they can lead the people around them to participate in making changes so stunting-free can be achieved. This research is limited due to its number of samples so further research or systematic review needs to be done in the future.

\section{Acknowledgment}

The Author thanks to Faculty of Medicine, Universitas Kristen Indonesia, class of 2020's chief for coordinating the questionnaire's distribution.

\section{References}

Abdi, I. N. I., Mapesa, J., \& Meme, J. (2021). Effect of routine vitamin A supplementation on nutritional status of children aged 6 - 59 months in Wajir country, Kenya. Internasional Journal of Profession Practice, 9(1), 1-5.

Aisyah, S., Syafar, M., \& Amiruddin, R. (2020). Pengaruh media sosial untuk meningkatkan pengetahuan dan sikap remaja tentang HIV dan AIDS di kota Parepare. JKMM, 3(1), 109 - 122. DOI: https://doi.org/10.30597/jkmm.v3i1.10299

Alam, F., Gautam, S., Noor, N., \& Moin, S. (2021). Role of maternal serum ferritin in gestational diabetes mellitus. Int J Cur Res Rev., 13(1), 161 -164. http://dx.doi.org/10.31782/IJCRR.2021.13121

Ambarsari, Z. (2020). Penggunaan Instagram sebagai media pembelajaran bahasa dan sastra Indonesia pada era 4.0. In Proceedings Seminar Nasional PBSI-III: 28 October 2020. Medan, Universitas Negeri Medan. 81-85.

Ampaabeng, S. K., \& Tan, C. M. (2013). The Long-Term Cognitive Consequences of Early Childhood Malnutrition: The Case of Famine in Ghana. Journal of Health Economics, 32, 1013-1027.

Asiki, G., Newton, R., Marions, L., Kamali, A., \& Smedan, L. (2019). The effect of childhood stunting and wasting on adolescent cardiovascular disease risk and educational achievement in rural Uganda: a retrospective cohort study. Glob Health Action, 12(1), 1626184. doi: 10.1080/16549716.2019.1626184.

Belachew, T., Hadley, C., Lindstrom, D., Gebremariam, A., Lachat, C., \& Kolsteren, P. (2011). Food insecurity, school absenteeism and educational attainment of adolescents in Jimma Zone Southwest Ethiopia: A Longitudinal Study. Nutrition Journal, 10, 29.

Bhutta, Z. A., Berkley, J. A., Bandsma, R. H. J., Kerac, M., Trehan, I., \& Briend, A. (2017). Severe childhood malnutrition. Nat Rev Dis Primers, 3, 1 - 44. DOI: 10.1038/nrdp.2017.67

Children with disabilities report. (2013). [https://www.unicef.org/sowc2013/report.html]. December 2018.

Grillo. L. P., \& Gigante, D. P. (2017). Evidence for the association between early childhood stunting and metabolic syndrome. Brazil: Springer, Cham.

Harerimana, J. (2020). Poverty trend and infant malnutrition in Rwanda (2020). Nutrition and Food Sciences Research, 7(3), 25 - 32.

Jiang, L., Yin, X., Chen, Y. H., Chen, Y., Jiang, W., Zheng, H., Huang, F. Q., Liu, B., Zhou, W., Q, L. W., \& Li, J. (2021). Proteomic analysis reveals ginsenoside $\mathrm{Rb} 1$ attenuates myocardial ischemia/reperfusion injury through inhibiting ROS production from mitochondria complex. Eur PMC., 11(4), $1703-1720$

Kurniasih, N. (2018). Buletin: Situasi balita pendek di Indonesia. Indonesia: Kementerian Kesehatan RI.

Lemeshow, Stanley, Hosmer, David, W., Klar, Janelle, Lwanga, Stephen Kaggwa, \& WHO. (1994) Adequacy of sample size in health studies. Chichester: Wiley dan WHO. 
Nadila, N. N. (2021). The relationship between nutritional status of stunting in children under five with tuberculosis incidence. Jurnal Medika Hutama, 2(2), 475-479. https://apps.who.int/iris/handle/10665/41607

Osei, R. D., \& Lambon-Quay Fio, M. P. (2021). Effects of long term malnutrition on education outcomes in Ghana: Evidence from a panel study. The European Journal of Development Research, 5(5), 6425 - 6430.

Prendergast, A., Humphrey, J. H. (2014). The stunting syndrome in developing countries. Paediatr Int Child Health, $34(4), 250-265$.

Ramadhani, E. (2019). Pemanfaatan media sosial Instagram sebagai media pembelajaran fisika terhadap motivasi belajar siswa kelas XI IPA 4 di SMAN 2 Banda Aceh. Undergraduate thesis. Universitas Syiah Kuala, Faculty of teacher training and education.

Samy, G., Shaalan, A. H., Mattar, M.K., Ahmed, H. H., Zaki, M. E., \& Abdallah, H. A. R. I. (2014). Oxidative stress status in nutritionally stunted children. The Gazette of the Egyptian Paediatric Association, 62(1), 28 - 33.

Sesriyani, L., \& Sukmawati, N. N. (2019). Analisis penggunaan Instagram sebagai media pembelajaran bahasa Inggris pada program studi Pendidikan Ekonomi. Jurnal Pendidikan, Hukum, dan Bisnis, 4(1), 9-15. 